\title{
Hubungan Kepemimpinan Bertanggung Jawab Terhadap Turnover Intention Pada Karyawan Bank Swasta Di Jakarta: Peran Mediasi Iklim Etis
}

\author{
Bimmo Dwi Baskoro ${ }^{1}$, Dwi Prasetyo ${ }^{2}$, Sudarmadji ${ }^{3}$ \\ ${ }^{1,3}$ Sekolah Tinggi Manajemen Labora, Jl. Palem Raja B7/7 Cakung, Jakarta Timur \\ ${ }^{2}$ Institut Daarul Qur'an Jakarta, Jl. Cipondoh Makmur Raya, Tangerang \\ Email : bimmodibi@gmail.com ${ }^{1}$,dwiprasetyo.sbm@gmail.com², \\ sudarmadji2506@gmail.com ${ }^{3}$
}

\begin{abstract}
ABSTRAK
Tujuan dari penelitian ini adalah untuk mengetahui sejauh mana iklim etis memediasi antara kepemimpinan yang bertanggung jawab dan niat pergantian karyawan (keluar karyawan). Teknik convenience sampling digunakan untuk mengumpulkan data dari karyawan tingkat cabang Bank swasta di Jakarta. Pendekatan analisis deskriptif dan structural equation modelling (SEM) digunakan menggunakan SPSS 22.0 dan Smart PLS 3.0. Berdasarkan hasil penelitian diketahui bahwa kepemimpinan bertanggung jawab berpengaruh signifikan terhadap iklim etis. Iklim etis berpengaruh negatif dan signifikan terhadap niat keluar karyawan. Iklim etis memediasi hubungan antara kepemimpinan yang bertanggung jawab dan niat untuk keluar (intensi keluar) karyawan.
\end{abstract}

Kata Kunci: iklim etis, kepemimpinan bertanggungjawab, karyawan, intensi keluar, Jakarta

\begin{abstract}
The purpose of the study was to find out the extent of the ethical climate of mediation between responsible leadership and employee turnover intentions. Convenience sampling techniques are used to collect data from private bank branch level employees in Jakarta. Descriptive analysis and structural equation modelling (SEM) approaches are used using SPSS 22.0 and Smart PLS 3.0. Based on the results of research it is known that responsible leadership has a significant influence on the ethical climate. The ethical climate negatively and significantly affects employee exit intentions. The ethical climate mediates the relationship between responsible leadership and turnover intention.
\end{abstract}

Keywords: ethical climate, responsible leadership, employees, turnover intentions, Jakarta

\section{PENDAHULUAN}

Penyimpangan etika oleh para pemimpin perusahaan di seluruh dunia mempengaruhi sebagian besar organisasi. Untuk tujuan ini, skandal Panama Papers menimbulkan beberapa pertanyaan mengenai ketersediaan para pemimpin secara global. Oleh karena itu, kebutuhan akan konsep kepemimpinan yang menunjukkan kepedulian terhadap bisnis sangat penting (Pless \& Maak, 2009). Para pemimpin perusahaan perlu 
dievaluasi terus-menerus karena para peneliti mengklaim bahwa ada kebutuhan yang mengerikan dari etika manajemen yang, bila tidak diberikan kepentingan yang tepat, kemudian dapat menyebabkan krisis ekonomi (Waldman \& Galvin, 2008).

Deskriptor kepemimpinan yang mapan seperti kepemimpinan transformasional, karismatik, partisipatif dan etis belum secara jelas mengakui gagasan tanggung jawab (Waldman \& Galvin, 2008). Di bidang perilaku organisasi, konsep kepemimpinan yang bertanggung jawab telah mengumpulkan perhatian (Amlan Haque, Fernando, \& Caputi, 2019). Tuntutan pada pemimpin meningkat untuk memimpin dengan cara yang bertanggung jawab tidak hanya untuk bisnis tetapi juga untuk semua pemangku kepentingan. Pemimpin memainkan peran penting dalam membangun iklim etis dalam organisasi apa pun.

Pemimpin organisasi memiliki pengaruh yang kuat dalam menciptakan iklim kerja yang etis (Neubert, Carlson, Kacmar, Roberts, \& Chonko, 2009). Pemimpin memainkan peran dominan dalam merancang kerangka moral organisasi (Ötken \& Cenkci, 2012). Namun, telah terjadi skeptisisme yang membesar tentang peran eksekutif perusahaan dalam mengembangkan dan menerapkan etika dalam bisnis. Prevalensi skandal bisnis dari surat perintah kepemimpinan yang lebih tinggi memberikan kepada kebijakan etika perusahaan dan praktik para pemimpin.

Skandal perusahaan dan penyimpangan etika telah menimbulkan pertanyaan tentang konsep dasar iklim etis, niat keluar, dan peran kepemimpinan yang bertanggung jawab (Fernando, 2016). Saat ini citra perusahaan menjadi kritis, dan tanggung jawab sosial perusahaan (CSR) sekarang dianggap sebagai sumber kehidupan organisasi (Demirtas \& Akdogan, 2015). Hal ini meningkatkan pentingnya manajer yang memberikan pengaruh yang signifikan dalam lingkungan tempat kerja. Peran manajer dan perilaku etis memberikan landasan moral kepada anggota staf (Mendonca, 2001) dan membantu dalam menetapkan suasana bersama dalam sebuah organisasi (Wright \& Goodstein, 2007). Sementara itu, kerangka moral organisasi tergantung pada kepemimpinan yang bertanggung jawab. Oleh karena itu, tantangan bagi kepemimpinan untuk membangun lingkungan dalam organisasi yang mempengaruhi karyawan dan dengan demikian mengurangi pergantian karyawan.

Kepemimpinan yang bertanggung jawab adalah proses mengembangkan dan mempertahankan kontak positif dengan semua pemangku kepentingan (Maak \& Pless, 
2006). Dengan demikian, kepemimpinan yang bertanggung jawab muncul sebagai wacana manajemen penting, dan tuntutan telah diajukan untuk kepemimpinan yang bertanggung jawab (Antunes \& Franco, 2016). Pada tahap utama pengembangan kepemimpinan yang bertanggung jawab, titik fokus adalah pada konseptualisasi dan tamasya nilai-nilai individu dan motivasi etis.

Banyak peneliti dari bidang perilaku organisasi telah menyelidiki dampak dari gaya kepemimpinan pada hasil karyawan. Namun, ada kurangnya penelitian tentang bagaimana dampak kepemimpinan yang bertanggung jawab terhadap hasil perilaku karyawan (A. Haque, Aydin, \& Uysal, 2017). Studi terbatas telah secara empiris mempelajari dampak kepemimpinan yang bertanggung jawab pada hasil karyawan dan organisasi. Penelitian sebelumnya telah menunjukkan bahwa kepemimpinan yang bertanggung jawab secara positif terkait dengan komitmen organisasi karyawan (Miska \& Mendenhall, 2018). Penelitian saat ini berfokus untuk mengatasi masalah ini, terutama dari sudut pandang sektor perbankan swasta di Jakarta karena adanya isu yang muncul dari kepemimpinan.

Teori CSR menyatakan bahwa ada tiga kewajiban umum organisasi kepada masyarakat: ekonomi, hukum dan etika (Stewart, 2011). Untuk memenuhi kewajiban ekonomi, sebuah organisasi harus memaksimalkan keuntungan dan menciptakan peluang kerja (Schwartz \& Carroll, 2003). Di sisi lain, organisasi mengikuti sistem hukum negara untuk memenuhi tanggung jawab hukum (Jamali, Safieddine, \& Rabbath, 2008). Akhirnya, untuk memenuhi tanggung jawab etis, organisasi mengikuti normanorma sosial. Fokus dari teori ini adalah bahwa organisasi mendukung masyarakat dengan memberikan kesempatan kerja sambil mengamati sistem hukum suatu negara dan mempertimbangkan nilai-nilai etika yang ditetapkan oleh norma-norma.

Akibatnya, tujuan dari penelitian ini adalah untuk memeriksa hubungan antara persepsi karyawan mengenai tanggapan kepemimpinan yang bertanggung jawab dan iklim etis. Penelitian ini juga bertujuan untuk menyelidiki tingkat dampak iklim etis terhadap niat karyawan untuk meninggalkan organisasi. Selanjutnya, penelitian ini meneliti peran mediasi iklim etis antara kepemimpinan yang bertanggung jawab dan niat untuk keluar. Penelitian ini dirancang untuk menjawab pertanyaan-pertanyaan berikut: 
Pertanyaan 1: Apakah ada hubungan yang signifikan antara kepemimpinan yang bertanggung jawab dan iklim etis?

Pertanyaan 2: Sejauh mana dampak iklim etis pada niat keluar bekerja?

Pertanyaan 3: Apakah iklim etis memediasi hubungan antara kepemimpinan yang bertanggung jawab dan niat keluar bekerja?

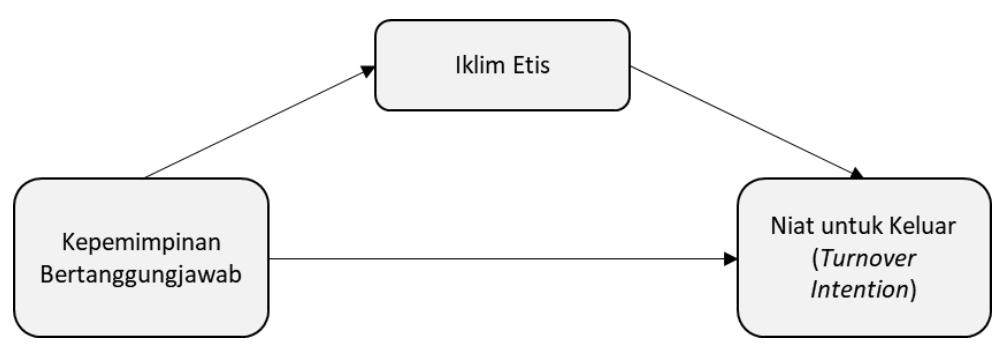

Gambar 1. Model Hipotesis

\section{METODE PENELITIAN}

Penelitian ini bersifat kuantitatif. Data dikumpulkan melalui eksplorasi dan paradigma interpretivisme. Sampel penelitian ini adalah karyawan yang bekerja di tingkat cabang di Bank swasta yang berada di Jakarta.

Pengumpulan data dilakukan dengan bantuan teknik convenience sampling. Data dikumpulkan dari karyawan bank yang bekerja di tingkat cabang di Jakarta. Peneliti mengumpulkan data melalui teknik convenience sampling. Setiap responden mengisi formulir survei yang mencakup empat bagian. Sebanyak 250 kuesioner didistribusikan dan setelah empat bulan, dan 201 kuesioner dikembalikan. Namun, dari 201, 168 kuesioner dianggap dapat digunakan. Oleh karena itu, tingkat respons penelitian ini adalah $67,2 \%$ (Tabel 1).

Tabel 1. Tingkat Pengembalian

\begin{tabular}{ccc}
\hline Aktivitas & Frekuensi & Persentase \\
\hline Kuesioner dikirim & 250 & 100 \\
\hline Kuesioner dikembalikan & 201 & 80,4 \\
\hline Kuesioner digunakan & 168 & 67,2 \\
\hline Kuesioner tidak digunakan & 33 & 13,2 \\
\hline
\end{tabular}

Instrumen penelitian yang digunakan dalam penelitian ini terdiri dari empat bagian. Bagian satu terdiri dari item pertanyaan yang berkaitan dengan rincian demografis responden. Bagian dua berisi item yang terkait dengan kepemimpinan yang bertanggung 
jawab; Bagian ketiga berisi item yang berkaitan dengan iklim etis; dan Bagian empat berisi item yang berkaitan dengan niat keluar. Setiap item dalam kuesioner diukur dengan skala Likert lima poin, dengan 1 dinyatakan sangat tidak setuju, dan 5 sangat setuju. Kepemimpinan yang bertanggung jawab dinilai menggunakan 14 item yang diadaptasi dari Voegtlin (2012). Iklim etis dinilai dengan menggunakan tujuh item yang diadaptasi dari Schwepker (2001). Niat untuk keluar dinilai oleh 3 item yang diadaptasi dari Cole \& Bruch (2006).

Untuk statistika deskriptif digunakan SPSS Versi 23 dan untuk analisis data menggunakan Smart PLS Versi 3. Tabel 2 memberikan karakteristik demografis. Pengumpulan data dari satu sumber dapat menyebabkan common method biases (Podsakoff, MacKenzie, Lee, \& Podsakoff, 2003). Untuk memeriksa adanya common method bias, Harman's single-factor test, digunakan sebagaimana disarankan oleh Podsakoff et al. (2003). Hasil dari Harman's single-factor test mengekstraksi 21 faktor, dan varians terbesar yang dijelaskan oleh faktor individu adalah 37,89\% yang kurang dari 50\%. Hal ini jelas menunjukkan bahwa tidak ada faktor tunggal yang menyebabkan varians dalam item.

Tabel 2. Karakter Demografik

\begin{tabular}{ccc}
\hline Variabel & Kategori & Jumlah \\
\hline Jenis Kelamin & Laki-Laki & 99 \\
& Perempuan & 69 \\
\hline Pendidikan & S-2 & 62 \\
& S-1 & 106 \\
\hline Umur & $20-30$ tahun & 67 \\
& $31-40$ tahun & 86 \\
& $41-50$ tahun & 12 \\
& $>50$ tahun & 3 \\
\hline Pengalaman Kerja & $<1$ tahun & 5 \\
& $1-5$ tahun & 100 \\
& $6-10$ tahun & 22 \\
& $11-15$ tahun & 30 \\
& $>15$ tahun & 11 \\
\hline Status Perkawinan & Belum Menikah & 66 \\
& Sudah Menikah & 102 \\
\hline
\end{tabular}

Keandalan dan validitas item pengukuran ditentukan untuk penilaian model pengukuran reflektif. Dua subtipe validitas, yaitu validitas konvergen dan diskriminan, digunakan untuk memeriksa validitas model (Joe F. Hair, Ringle, \& Sarstedt, 2011). 


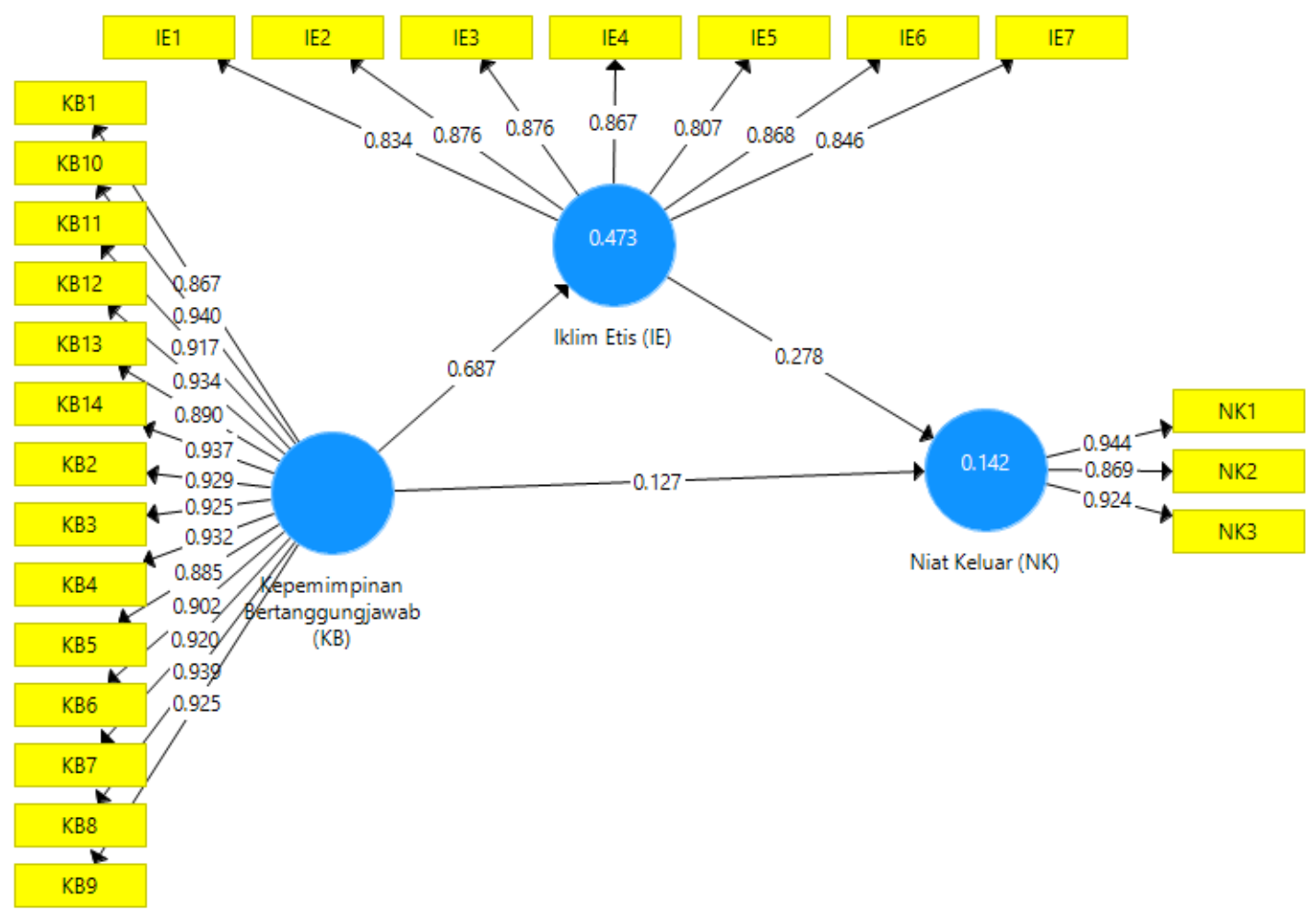

Gambar 2. Model Pengukuran

Construct validity. Analisis faktor digunakan untuk mengkonfirmasi validitas konstruksi. Nilai loading 0,5 dianggap sebagai cut-off (Joe F. Hair, Sarstedt, Hopkins, \& Kuppelwieser, 2014). Item yang memiliki nilai kurang dari 0,5 dihapus. Tabel 3 menunjukkan loading factor semua item kami yang berada di atas 0,5, seperti yang direkomendasikan oleh Hair et al. (2010).

Tabel 3. Nilai Factor Loading

\begin{tabular}{|c|c|c|c|}
\hline Konstruk & Item & Loading & Item yang dihapus \\
\hline \multirow{7}{*}{ Iklim Etis } & IE1 & 0.834 & \multirow{7}{*}{ Tidak Ada } \\
\hline & IE2 & 0.876 & \\
\hline & IE3 & 0.876 & \\
\hline & IE4 & 0.867 & \\
\hline & IE5 & 0.807 & \\
\hline & IE6 & 0.868 & \\
\hline & IE7 & 0.846 & \\
\hline \multirow{4}{*}{ Kepemimpinan Bertanggungjawab } & KB1 & 0.867 & \multirow{4}{*}{ Tidak Ada } \\
\hline & KB10 & 0.94 & \\
\hline & KB11 & 0.917 & \\
\hline & KB12 & 0.934 & \\
\hline
\end{tabular}




\begin{tabular}{|c|c|c|c|}
\hline Konstruk & Item & Loading & Item yang dihapus \\
\hline & KB13 & 0.89 & \\
\hline & KB14 & 0.937 & \\
\hline & $\mathrm{KB} 2$ & 0.929 & \\
\hline & KB3 & 0.925 & \\
\hline & KB4 & 0.932 & \\
\hline & KB5 & 0.885 & \\
\hline & KB6 & 0.902 & \\
\hline & KB7 & 0.92 & \\
\hline & KB8 & 0.939 & \\
\hline & KB9 & 0.925 & \\
\hline \multirow{3}{*}{ Niat Keluar (Turnover Intention) } & NK1 & 0.944 & \multirow{3}{*}{ Tidak Ada } \\
\hline & NK2 & 0.869 & \\
\hline & NK3 & 0.924 & \\
\hline
\end{tabular}

Convergent validity. Untuk penilaian model pengukuran reflektif, kita perlu memeriksa composite reliability (CR) dan average variance extracted (AVE) (Hair, Sarstedt, \& Ringle, 2019). Untuk composite reliability, nilai loading berkisar antara 0,7 dan 0,9 ditemukan dalam penelitian ini. Namun, nilainya tidak boleh melebihi 0,95 karena akan menunjukkan multikolinearitas (Hair et al., 2011). Semua item variabel memiliki CR antara 0,921 dan 0,935 seperti yang ditunjukkan pada Tabel 4 dimana lebih besar dari 0,7 .

Setelah composite reliability, Nilai AVE digunakan untuk memeriksa validitas konvergen. AVE lebih besar dari atau sama dengan 0,5 menunjukkan bahwa variabel laten menjelaskan setidaknya setengah dari varians indikatornya (Joe F. Hair et al., 2011). Hasil penelitian menunjukkan bahwa nilai AVE dari semua konstruksi dalam penelitian ini lebih besar dari 0,5 sehingga memenuhi nilai cut-off 0,5 seperti yang direkomendasikan oleh (Joe F. Hair et al., 2014) (lihat Tabel 4).

Tabel 4. Nilai Composite Reliability dan AVE

\begin{tabular}{cccc}
\hline Konstruk & Cronbach's Alpha & Composite Reliability & $\boldsymbol{A V E}$ \\
\hline Iklim Etis & 0.938 & 0.950 & 0.729 \\
\hline Kepemimpinan Bertanggungjawab & 0.986 & 0.987 & 0.842 \\
\hline Niat Keluar & 0.900 & 0.937 & 0.833 \\
\hline
\end{tabular}

Discriminant validity. Validitas diskriminan digunakan untuk memeriksa bahwa skala yang digunakan tidak tumpang tindih. Hal ini menunjukkan bahwa item 
pengukuran harus berbeda dan tidak boleh sangat berkorelasi. Varians variabel yang diamati akan dilakukan dalam kasus tidak adanya validitas diskriminan. Kriteria untuk mengevaluasi validitas diskriminan adalah cross loadings, Fornell and Larcker criterion, dan Heterotrait-Monotrait ratio (HTMT). Dalam penelitian ini, validitas diskriminan diukur dengan HTMT (Henseler, Ringle, \& Sarstedt, 2015). Henseler et al. (2015) menyarankan nilai kurang dari 0,9 dalam HTMT dapat diterima (Tabel 5).

Tabel 5. Nilai HTMT

\begin{tabular}{cccc}
\hline Konstruk & $\begin{array}{c}\text { Iklim } \\
\text { Etis }\end{array}$ & $\begin{array}{c}\text { Kepemimpinan } \\
\text { Bertanggungjawab }\end{array}$ & $\begin{array}{c}\text { Niat } \\
\text { Keluar }\end{array}$ \\
\hline Iklim Etis & & & \\
\hline Kepemimpinan Bertanggungjawab & 0.702 & & \\
\hline Niat Keluar & 0.391 & 0.332 \\
\hline
\end{tabular}

Model Struktural. Untuk menguji hipotesis penelitian ini, teknik pemodelan persamaan struktural digunakan menggunakan Smart PLS versi 3.2.8. SEM mampu menguji semua hipotesis yang mencakup efek langsung dan tidak langsung secara bersamaan sehingga mengurangi kemungkinan kesalahan bias. Selain itu, bootstrapping 5.000 resamples dengan interval kepercayaan $95 \%$ juga dilakukan.

Hasil efek langsung menunjukkan bahwa kepemimpinan yang bertanggung jawab secara positif dan signifikan terkait dengan iklim etis ( $\mathrm{t}$ hitung $=2,897$; $p$-value $<0,05$ ). Oleh karena itu, H1 didukung. Iklim etis ditemukan secara signifikan terkait negatif terhadap niat untuk keluar ( $\mathrm{t}$ hitung $=4,613$; $p$-value $<0,05$ ); dengan demikian, $\mathrm{H} 2$ diterima (lihat Tabel 6). Adapun efek mediasi, hasil bootstrapping menunjukkan bahwa iklim etis memediasi antara kepemimpinan yang bertanggung jawab dan niat keluar $(\mathrm{t}$ hitung $=2,457 ; \mathrm{p}<0,05)$. Dengan demikian, H3 diterima (lihat Tabel 7).

Tabel 6. Hasil Model Struktural

\begin{tabular}{cccc}
\hline Hubungan & Beta & t-statistics & p-value \\
\hline $\mathrm{EI} \rightarrow \mathrm{NK}$ & $-0,321$ & 4,613 & 0,000 \\
\hline $\mathrm{KB} \rightarrow \mathrm{EI}$ & 0,232 & 2,897 & 0,004 \\
\hline
\end{tabular}

Tabel 7. Hasil Model Struktural (Efek Mediasi)

\begin{tabular}{cccc}
\hline Hubungan & Beta & t-statistics & p-value \\
\hline $\mathrm{KB} \rightarrow \mathrm{EI} \rightarrow \mathrm{NK}$ & $-0,074$ & 2,457 & 0,014 \\
\hline
\end{tabular}


Koefisien Determinasi $\left(\boldsymbol{R}^{2}\right)$. Koefisien determinasi $\left(\mathrm{R}^{2}\right)$ juga digunakan untuk menilai model struktural konstruks endogen (Hair et al., 2014). Nilai $\mathrm{R}^{2}$ sebesar 0,25 menunjukkan efek kecil, 0,50 efek sedang, and 0,75 menunjukkan efek substansial (Hair et al., 2016) sebagaimana pada Tabel 8. Nilai $\mathrm{R}^{2}$ untuk semua konstruk dependen (Iklim Etis dan Niat Keluar) ditunjukkan pada Tabel 8. $\mathrm{R}^{2}$ untuk variabel terikat niat keluar sebesar 10,2\%. Temuan ini menunjukkan varians kecil.

Tabel 8. Variansi Konstruk Laten Variabel

\begin{tabular}{|c|c|}
\hline Konstruk & Variansi $\mathbf{R}^{2}(\%)$ \\
\hline Iklim Etis & 5,0 \\
\hline Niat Keluar & 10,2 \\
\hline
\end{tabular}

Penilaian relevansi prediktif. Uji $\mathrm{Q}^{2}$ tes digunakan untuk mengakses relevansi prediktif dalam model. Hal ini dinilai melalui proses blindfolding. Hasil redundansi yang divalidasi silang membantu untuk mengukur penerimaan model untuk memprediksi variabel dependen. Aturan praktis yang didefinisikan oleh peneliti adalah bahwa model yang nilai $\mathrm{Q}^{2}$-nya lebih besar dari "0" memiliki relevansi prediktif, dan model itu memiliki kemampuan untuk mendefinisikan hubungan, sedangkan nilai $\mathrm{Q}^{2}$ bernilai 0 dan kurang dari "0" menunjukkan bahwa model tersebut tidak mengandung pengaruh prediktif (Geisser, 1974). Tabel 9 menunjukkan relevansi yang luar biasa dari 0,069 untuk konstruks endogen.

Tabel 9. Nilai Predictive Relevance

\begin{tabular}{cccc}
\hline Konstruk & Nilai SSO & $\begin{array}{c}\text { Nilai } \\
\text { SSE }\end{array}$ & $\boldsymbol{Q}^{2}$ \\
\hline Niat Keluar & 505 & 468 & 0,079 \\
\hline
\end{tabular}

Keterangan: $Q^{2}=1-S S O / S S E$

\section{HASIL DAN PEMBAHASAN}

Salah satu tujuan utama organisasi adalah untuk memaksimalkan kekayaan pemegang saham, yang menempatkan berbagai tanggung jawab kepada para pemimpin perusahaan. Saat ini, organisasi telah menyadari bahwa untuk keberlanjutan, penting untuk membangun lingkungan kerja iklim etis dalam organisasi, sedangkan perilaku tidak etis mempengaruhi kinerja organisasi. Konsep kepemimpinan yang bertanggung jawab dan iklim etis dianggap penting di sektor perbankan seperti sektor jasa lainnya 
dan diperkirakan bahwa kepemimpinan yang bertanggung jawab di sektor perbankan memiliki dampak yang kuat pada pergantian karyawan. Dari sudut pandang ini, mengungkapkan peran mediasi iklim etis antara kepemimpinan etis dan pergantian karyawan perbankan dipelajari.

Iklim etis adalah subjek penelitian penting untuk sektor keuangan karena mempengaruhi hubungan organisasi pelanggan. Perilaku tidak etis di sektor perbankan merusak citra bank, mengurangi efisiensi kerja tim dan meningkatkan niat keluar. Sebagai hasil dari penelitian ini, kesimpulannya adalah bahwa kepemimpinan yang bertanggung jawab memiliki korelasi positif dengan iklim etis di sektor perbankan swasta Jakarta. Selain itu, disimpulkan bahwa iklim etis memiliki korelasi negatif yang signifikan dengan pergantian karyawan.

Hasil penelitian kami mengkonfirmasi temuan penelitian yang dilakukan oleh Schluter et al. (2008) di sektor kesehatan dimana iklim etis memiliki korelasi negatif yang signifikan dengan niat keluar karyawan. Penelitian yang dilakukan oleh Yasin et al. (2020) juga menggambarkan bahwa iklim etis memiliki korelasi negatif dengan niat keluar. Hasil lain dari penelitian ini adalah bahwa iklim etis menengahi antara kepemimpinan yang bertanggung jawab dan pergantian karyawan di sektor perbankan Pakistan. Hasil yang sama ditunjukkan oleh studi Demirtas \& Akdogan (2015).

Terlepas dari kontribusi literatur yang relevan dengan disiplin keuangan, penelitian ini juga mencakup beberapa batasan. Karena sampling yang terbatas pada sektor perbankan dan satu bank, sulit untuk membuat evaluasi umum di sektor keuangan. Di sisi lain, besarnya sektor perbankan di tanah air membuat temuan sulit dievaluasi. Disarankan bahwa rentang pengambilan sampel yang lebih luas untuk penelitian di masa depan diperlukan untuk memberikan fitur penilaian utama untuk penelitian di masa depan.

Studi ini memeriksa korelasi antara kepemimpinan yang bertanggung jawab dan niat keluar dan peran mediasi iklim etis. Hasilnya menentukan pentingnya mempelajari kepemimpinan yang bertanggung jawab dari perspektif karyawan, dan mereka menyebarkan dan memvalidasi literatur tentang hubungan antara kepemimpinan yang bertanggung jawab, iklim etis dan niat keluar dalam banyak hal. Seperti yang diprediksi dalam H1, kepemimpinan yang bertanggung jawab secara signifikan terkait positif dengan iklim etis. Hubungan positif antara kepemimpinan yang bertanggung jawab dan 
iklim etis menyimpulkan bahwa kepemimpinan yang bertanggung jawab menciptakan iklim etis dan iklim etis membantu mengurangi pergantian karyawan. Hasil ini mengkonfirmasi temuan Doh et al. (2012) dan Yasin et al. (2020) yang mengekspos kepemimpinan yang bertanggung jawab sebagai konstruksi dominan yang mengikat karyawan dengan organisasi. Sifat relasional yang melekat dari kepemimpinan yang bertanggung jawab menciptakan daya tarik dalam karyawan bagi para pemimpin dan organisasi, sehingga meningkatkan perasaan memiliki pada karyawan. Perasaan ini dapat menyebabkan penurunan pergantian karyawan.

Seperti yang diprediksi pada $\mathrm{H} 2$, iklim etis terkait negatif dengan niat keluar. Untuk membenarkan hubungan negatif ini, kita menggunakan kontrak psikologis. Menurut Raja et al. (2004), ada hubungan negatif antara kontrak relasional karyawan dan niat untuk berhenti. Hasilnya mengkonfirmasi penelitian sebelumnya bahwa kontrak psikologis yang rusak diamati dalam perilaku penarikan yang sering menyertai niat untuk pergi (Christian \& Ellis, 2014). Hasil ini juga mengkonfirmasi temuan sebelumnya (Yasin et al., 2020). Korelasi negatif antara iklim etis dan niat keluar karyawan menjelaskan pentingnya iklim etis dalam suatu organisasi ketika dipelajari dari sudut pandang karyawan. Hal ini mengungkapkan bahwa kepemimpinan yang bertanggung jawab membangun hubungan yang kuat dengan karyawan, menganggap karyawan sebagai pemangku kepentingan utama organisasi dan sebagai tanggapan mempesona karyawan dan mengurangi niat karyawan untuk meninggalkan organisasi.

Akhirnya, hasil H3 menunjukkan bahwa iklim etis memainkan peran penting dalam mengukur efektivitas kepemimpinan yang bertanggung jawab untuk mengurangi niat keluar karyawan. Hasil ini memperpanjang klaim konseptual peneliti bahwa niat pergantian karyawan tergantung pada gaya kepemimpinan dan iklim etis (Lee, Hung, \& Chen, 2012; Yasin et al., 2020). Iklim etis ditemukan sebagai mediator antara kepemimpinan yang bertanggung jawab dan niat keluar dari perusahaan.

\section{SIMPULAN}

Dengan menggunakan teori CSR, penelitian ini melaporkan hubungan antara kepemimpinan yang bertanggung jawab dan iklim etis, dan iklim etis sebagai mediator antara kepemimpinan yang bertanggung jawab dan niat untuk keluar. Mengambil pandangan yang berbeda dari studi sebelumnya yang meneliti dampak kepemimpinan 
etis pada iklim etis, penelitian ini menerapkan iklim etis sebagai mediator antara kepemimpinan yang bertanggung jawab dan niat untuk keluar. Hasilnya mengungkapkan bahwa kepemimpinan yang bertanggung jawab mempengaruhi iklim etis secara signifikan. Selain itu, iklim etis memediasi hubungan antara kepemimpinan yang bertanggung jawab dan komitmen organisasi. Akibatnya, temuan penelitian menunjukkan bahwa kepemimpinan yang bertanggung jawab menciptakan iklim etis dalam organisasi dan karena itu mengurangi niat pergantian karyawan.

\section{DAFTAR PUSTAKA}

Antunes, A., \& Franco, M. (2016). How people in organizations make sense of responsible leadership practices: Multiple case studies. Leadership and Organization Development Journal, 37(1), 126-152. https://doi.org/10.1108/LODJ-04-2014-0084

Christian, J. S., \& Ellis, A. P. J. (2014). The Crucial Role of Turnover Intentions in Transforming Moral Disengagement Into Deviant Behavior at Work. Journal of Business Ethics, 119(2), 193-208. https://doi.org/10.1007/s10551-013-1631-4

Cole, M. S., \& Bruch, H. (2006). Organizational identity strength, identification, and commitment and their relationships to turnover intention: does organizational hierarchy matter? Journal of Organizational Behavior, 27, 585-605. https://doi.org/10.1002/job.378

Demirtas, O., \& Akdogan, A. A. (2015). The Effect of Ethical Leadership Behavior on Ethical Climate, Turnover Intention, and Affective Commitment. Journal of Business Ethics, 130(1), 59-67. https://doi.org/10.1007/s10551-014-2196-6

Doh, J. P., Stumpf, S. A., \& Tymon, W. G. (2012). Responsible leadership helps retain talent in India. Responsible Leadership, 85-100. https://doi.org/10.1007/s10551011-1018-3

Fernando, M. (2016). Leading responsibly in the Asian century. Leading Responsibly in the Asian Century. https://doi.org/10.1007/978-3-319-21789-5

Geisser, S. (1974). A predictive approach to the random effect model. Biometrika, 61(1), 101-107. https://doi.org/10.1093/biomet/61.1.101

Hair, Joe F., Ringle, C. M., \& Sarstedt, M. (2011). PLS-SEM: Indeed a silver bullet. Journal of Marketing Theory and Practice, 19(2), 139-152. https://doi.org/10.2753/MTP1069-6679190202

Hair, Joe F., Sarstedt, M., Hopkins, L., \& Kuppelwieser, V. G. (2014). Partial least squares structural equation modeling (PLS-SEM): An emerging tool in business research. European Business Review, 26(2), 106-121. https://doi.org/10.1108/EBR-10-2013-0128

Hair, Joseph F., Sarstedt, M., \& Ringle, C. M. (2019). Rethinking some of the 
rethinking of partial least squares. European Journal of Marketing, 53(4), 566584. https://doi.org/10.1108/EJM-10-2018-0665

Haque, A., Aydin, E., \& Uysal, E. (2017). A comparison of effectiveness of global leaders and domestic leaders in electronic retail industry. Global Journal of Management and Business Research: G Interdisciplinary, 17(3), 1-16.

Haque, Amlan, Fernando, M., \& Caputi, P. (2019). The Relationship Between Responsible Leadership and Organisational Commitment and the Mediating Effect of Employee Turnover Intentions: An Empirical Study with Australian Employees. Journal of Business Ethics, 156(3), 759-774. https://doi.org/10.1007/s10551-0173575-6

Henseler, J., Ringle, C. M., \& Sarstedt, M. (2015). A new criterion for assessing discriminant validity in variance-based structural equation modeling. Journal of the Academy of Marketing Science, 43(1), 115-135. https://doi.org/10.1007/s11747014-0403-8

Jamali, D., Safieddine, A. M., \& Rabbath, M. (2008). Corporate governance and corporate social responsibility synergies and interrelationships. Corporate Governance: An International Review, 16(5), 443-459. https://doi.org/10.1111/j.1467-8683.2008.00702.x

Lee, D.-C., Hung, L.-M., \& Chen, M.-L. (2012). Empirical Study on the Influence among Corporate Sponsorship, Organizational Commitment, Organizational Cohesiveness and Turnover Intention. Journal of Management and Sustainability, 2(2), 43-53. https://doi.org/10.5539/jms.v2n2p43

Maak, T., \& Pless, N. M. (2006). Responsible leadership in a stakeholder society - A relational perspective. Journal of Business Ethics, 66(1), 99-115. https://doi.org/10.1007/s10551-006-9047-z

Mendonca, M. (2001). Preparing for ethical leadership in organizations. Canadian Journal of Administrative Sciences, 18(4), 266-276. https://doi.org/10.1111/j.1936-4490.2001.tb00262.x

Miska, C., \& Mendenhall, M. E. (2018). Responsible Leadership: A Mapping of Extant Research and Future Directions. Journal of Business Ethics, 148(1), 117-134. https://doi.org/10.1007/s10551-015-2999-0

Neubert, M. J., Carlson, D. S., Kacmar, K. M., Roberts, J. A., \& Chonko, L. B. (2009). The virtuous influence of ethical leadership behavior: Evidence from the field. Journal of Business Ethics, 90(2), 157-170. https://doi.org/10.1007/s10551-0090037-9

Ötken, A. B., \& Cenkci, T. (2012). The Impact of Paternalistic Leadership on Ethical Climate: The Moderating Role of Trust in Leader. Journal of Business Ethics, 108(4), 525-536. https://doi.org/10.1007/s10551-011-1108-2

Pless, N., \& Maak, T. (2009). Responsible leaders as agents of world benefit: Learnings from "project ulysses." Journal of Business Ethics, 85(1), 59-71. https://doi.org/10.1007/s10551-008-9947-1 
Podsakoff, P. M., MacKenzie, S. B., Lee, J. Y., \& Podsakoff, N. P. (2003). Common Method Biases in Behavioral Research: A Critical Review of the Literature and Recommended Remedies. Journal of Applied Psychology, 88(5), 879-903. https://doi.org/10.1037/0021-9010.88.5.879

Raja, U., Johns, G., \& Ntalianis, F. (2004). The impact of personality on psychological contracts. Academy of Management Journal, 47(3), 350-367. https://doi.org/10.2307/20159586

Schluter, J., Winch, S., Holzhauser, K., \& Henderson, A. (2008). Nurses' moral sensitivity and hospital ethical climate: a literature review. Nurs Ethics, 15(3), 304-321. https://doi.org/10.1177/0969733007088357

Schwartz, M. S., \& Carroll, A. B. (2003). Corporate social responsibility: a threedomain approach. Business Ethics Quarterly, 13(4), 503-530. https://doi.org/10.2307/3857969

Schwepker, C. H. (2001). Ethical climate's relationship to job satisfaction, organizational commitment, and turnover intention in the salesforce. Journal of Business Research, 54, 39-52. https://doi.org/10.1016/S0148-2963(00)00125-9

Stewart, R. W. (2011). You Support Diversity, But Are You Ethical? Examining the Interactive Effects of Diversity and Ethical Climate Perceptions on Turnover Intentions. Journal of Business Ethics, 99(3), 453-465. https://doi.org/10.1007/s10551-010-0663-2

Voegtlin, C. (2012). Development of a scale measuring discursive responsible leadership. Responsible Leadership, 57-73. https://doi.org/10.1007/s10551-0111020-9

Waldman, D. A., \& Galvin, B. M. (2008). Alternative Perspectives of Responsible Leadership. Organizational Dynamics, 37(4), 327-341. https://doi.org/10.1016/j.orgdyn.2008.07.001

Wright, T. A., \& Goodstein, J. (2007). Character is not dead in management research: A review of individual character and organizational-level virtue. Journal of Management, 33(6), 928-958. https://doi.org/10.1177/0149206307307644

Yasin, R., Namoco, S. O., Jauhar, J., Abdul Rahim, N. F., \& Zia, N. U. (2020). Responsible leadership an obstacle for turnover intention. Social Responsibility Journal, (March). https://doi.org/10.1108/SRJ-03-2020-0092 